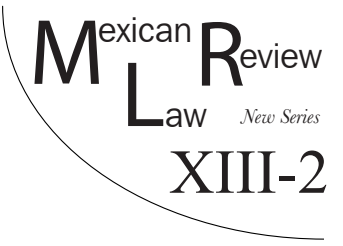

\title{
MUNICIPALITIES AS PART OF THE SYSTEM TO CONTROL GRIMINAL ASSETS IN MEXICO
}

\author{
Pedro Rubén Torres EstradA*
}

\begin{abstract}
Within a national system of control of criminal assets, the role of municipalities is strategic. According to their constitutional faculties, municipalities should develop and feed databases containing relevant information that contributes to the control of the criminal patrimonial and economic structures. An analysis of primary and secondary sources of information was used to identify the databases that are generated or that should be generated by the municipalities, considering the functions and powers that the constitution, laws, and regulations assign to each of the dependencies that integrate the municipal government. Although some municipal agencies keep track of their activities using databases, they do not have a structure that allows the exploitation of information. Moreover, some municipalities do not have structured public policies aimed at combating the patrimonial and economic structures of crime. Finally, municipalities are an important source of information that can contribute to law enforcement structures in the development of investigations aimed at weakening the financial and patrimonial structures of crime. This article showes the importance and utility of municipalities in the combat against assets generated by crime and the need to implement public policies intended to weaken the economic and patrimonial criminal structures. Currently, there are no previous studies on this subject in the national literature.
\end{abstract}

KEYWORDS: Operations with resources of illicit origin, municipal governments, databases, fight against crime-related assets, information analysis units.

Resumen: El papel de los municipios dentro de un sistema nacional de ataque de activos al crimen resulta estratégico, ya que estos, según sus competencias constitucionales, desarrollan y alimentan bases de datos que contienen información relevante que puede contribuir al ataque de las estructuras patrimonia-

* Researcher and Professor at the Escuela de Gobierno y Transformación Pública of the Instituto Tecnológico y de Estudios Superiores de Monterrey. Email: pedro.torres@tec.mx. We would like to thank the municipality of General Escobedo for all the information it provided us, and for their trust and support in the writing of this article. Special thanks to its municipal president (Clara Luz Flores) and its treasurer (Cesar Leija). 
Esta revista forma parte del acervo de la Biblioteca Jurídica Virtual del Instituto de Investigaciones Jurídicas de la UNAM

les y económicas de los delincuentes. Se realizó una recopilación de información de fuentes primarias y secundarias para identificar las bases de datos que generan o que deberían generar los municipios, teniendo en cuenta las funciones y atribuciones que la constitución, las leyes y los reglamentos le asignan a cada una de las dependencias que integran el gobierno municipal. Se pudo identificar que, si bien algunas dependencias municipales llevan el registro de sus actividades empleando bases de datos, estas no cuentan con una estructura que permita la explotación de la información; se identificó que los municipios no cuentan con políticas públicas estructuradas que se orienten al combate de las estructuras patrimoniales y económicas de la delincuencia. Los municipios son fuente importante de información que puede contribuir a las estructuras procuradoras de justicia en el desarrollo de investigaciones orientadas a debilitar las estructuras financieras y patrimoniales del crimen. Este trabajo muestra la importancia y la utilidad de los municipios en el combate contra los activos generados por la delincuencia y la necesidad de establecer políticas públicas orientadas al debilitamiento de las estructuras económicas y patrimoniales de las estructuras criminales. Actualmente, no existen estudios previos sobre el tema en la literatura nacional.

Palabras clave: Operaciones con recursos de procedencia ilícita, gobiernos municipales, bases de datos, ataque de activos de la delincuencia, unidades de análisis de información.

\section{Table of Contents}

I. INTRODUCTION

II. The Gurrent State of Public Policies in Municipalities.

III. Constitutional Municipal Faculties that Generate the Databases Required to Implement the Public Policies to Control Griminal Assets

IV. Municipal Organization and Databases................................... 70

V. Municipal Tax Information Analysis Areas.............................. 77

VI. The Unit's Structure and Basic Products................................ 78

VII. Conclusion: Implementation and Consolidation Risks of THESE NEW UNITS

VIII. ANNEXES

Information, information, information. I can't make bricks without clay... It is a mistake to theorize before obtaining information. Insensibly, one begins to distort facts to make them fit into theories instead of inserting theories into facts. 


\section{INTRODUCTION}

When we think about Transactions with Illegally Obtained Resources (ORPI's for their acronym in Spanish), we sometimes recall tax havens such as the Cayman Islands, Andorra or Switzerland, or complex transactions using virtual coins in the dark web. Although the above is part of the phenomenon and means used by criminals to move and spend the money obtained from their crimes, it is important to say that in Mexico the minority of criminals use this type of maneuvers, although they tend to be the ones that move larger amounts of money. ${ }^{1}$ The money laundered in Mexico in the most part results from three activities: (1) organized crime, (2) corruption, (3) tax evasion. ${ }^{2}$

Most criminals in Mexico depend on less complex mechanisms to use the money obtained from their crimes, such as the purchase of rustic agricultural or urban land by people who lend their names to carry out the operation as "figureheads". It is in this aspect where the role played by the states and municipalities represents an important part of the public policy machinery to control criminal assets and tools, both for organized and common crimes, in order to develop a national information system to control criminal assets.

This leads us to say that being aware of criminals' patrimonial and economic profiles is a key element of the security strategy and the justice system. In this sense, we believe that municipalities are the first barrier and institutional factor of the framework required to identify risks or generate alerts on possible money launderers in a given community. Clearly, municipalities cannot investigate this offence directly, but they can inform other federal or state entities of unusual behaviors or abnormal trends or patterns, just like banks, public notaries or jewelry stores do, and even more so since it is in the local public interest. ${ }^{3}$

Although formally it is a constitutional and legal obligation, ${ }^{4}$ municipalities normally have first-hand information on who is buying or registering (in case of straw men) land, houses or buildings; who is building or developing real es-

1 Proceso, México, virtual "paraíso" para el lavado de dinero: GAFI, Proceso, (Jan. 03, 2019), available at https://wrwre.proceso.com.mx/517149/mexico-virtual-paraiso-para-el-lavado-de-dinero-gafi.

2 Fatf \& Gafilat, Mutal Evaluation Report (2018).

3 Article 45 of the Federal Act for the Prevention and Identification of Transactions with Illegally Obtained Resources: "The Ministry and the Public Prosecutor's Office... may enter into agreements with the authorities that control the identification documents referred to in this article in order establish remote consultation systems". See, Ley Federal para la Prevención e Identificación de Operaciones con Recursos de Procedencia Ilícita [L.F.P.I.O.R.P.I] [Federal Act for the Prevention and Identification of Transactions with Illegally Obtained Resources] as amended, Diario Oficial de la Federación [D.O.F], 17 de octubre de 2012 (Mex.).

4 Article 10 of the General Files' Act: "Each regulated entity is responsible for organizing and preserving its files and operating its institutional system..."; Article 11: "The regulated entity shall organize, control and preserve the registry documents it produces, receives, obtains, acquires, transforms or possess in a homogeneous manner, in accordance with its faculties, com- 
tate properties; who is buying vehicles outside their usual pattern, who is making donations to public or private organizations, and who is making atypical investments in kind or in cash in political campaigns (some of this information must be public, such as donations to political institutions). ${ }^{5}$

When the money obtained from criminal activities becomes part of politics - for example when votes are bought through cash payments -, corruption increases and public institutions lose strength; ${ }^{6}$ this phenomenon translates into clientelism, reorientation of public policy and self-enrichment. ${ }^{7}$ Afterwards, those who invested in political campaigns go back to collect on their contributions, either in cash or in protection from the local authorities.

The municipalities cannot issue a warning based on testimonies without official and verifiable information. For this purpose, municipal authorities must order their patrimonial and fiscal information to be able to issue alerts that can activate the involvement of prosecutors' offices or other instances, such as municipal, state or federal tax authorities.

This article seeks to answer the following research question: Can the creation of Municipal Information Analysis Units help to fight criminal financial structures using the information bases generated by the municipalities?

Based on the corresponding constitutional faculties, this will be the method used to identify the databases that must exist in a municipality and the intelligence products that can be developed.

Municipal authorities will ask themselves what they gain from this measure, especially if they think that the illegal money that comes into their community fosters its economy or even activates it. However, the phenomenon of regions such as Michoacán and Tamaulipas demonstrate that the illegal money present in those states generates disputes and retaliations between groups, ${ }^{8}$ which,

petencies, skills or functions...". See, Ley General de Archivos [L.G.A] [General Files' Act], Diario Oficial de la Federación [D.O.F], 15 de junio de 2018 (Mex.).

5 Article 30 of the General Political Parties' Act: “(I) The reports they are under the obligation to present in terms of the provisions of this Law, the patrimonial standing of the political party... as well as the annexes that form an integral part of the above stated documents, list of donors and the amounts contributed by each one of them". See, Ley General de Partidos Políticos [L.G.P.P] [General Political Parties' Act], Diario Oficial de la Federación [D.O.F], 23 de mayo de 2014 (Mex.).

6 The General Electoral Institutions and Procedures Law, in its articles 443, 446, 445, states the type of offenses that can be committed by political parties, contenders, candidates, precandidates or candidates for elective office, as well as challengers and independent candidates. Additionally, in articles 9 and 15 the Electoral Offenses' General Law details the fines to be imposed on partisan officers or candidates that commit electoral offenses. See, Ley General de Instituciones y Procedimientos Electorales [L.G.I.P.E] [General Electoral Institutions and Procedures Law] as amended, Diario Oficial de la Federación [D.O.F], 23 de mayo de 2014 (Mex.).

7 Andreas Schedler, "El voto es nuestro". Cómo los ciudadanos mexicanos perciben el clientelismo electoral, 1 Rev. Mex. DE Soc. 57, 94 (2004).

8 According to the National Institute of Statistics and Geography - INEGI (2019), in 2012 Mexico City and the states of Mexico, Jalisco, Quintana Roo, Baja California, Nuevo León, 
in time, negatively affect the municipality in the form of violence and death, lack of investment, loss of land surplus value, ${ }^{9}$ lack of competitiveness ${ }^{10}$ and the creation of success stereotypes based on illegally obtained resources, which ultimately end up challenging and even subjecting municipal authorities. That is to say, it is a monster that turns against the municipality, as well as against most of its citizens and their assets.

\section{The Gurrent State of Public Policies in Municipalities}

In general terms, the Constitution of the United Mexican States and the National Institute of Statistics and Geography (INEGI for its acronym in Spanish) ${ }^{11}$ define municipalities as the basic political-administrative organization and division unit of the country's territory. Currently, Mexico is divided into 32 states and 2,457 municipalities. Oaxaca, Puebla and Veracruz have the largest number of municipalities, with 570 municipalities in Oaxaca, 217 in Puebla and 215 in Veracruz.

Mexican municipalities can be classified into four broad categories: rural, semi-urban, urban and metropolitan. ${ }^{12}$ Rural municipalities are characterized by developing activities related to the primary sector: livestock, agriculture, fishing and mining; the inhabitants of these municipalities tend to migrate to cities and towns where there is a more diversified economic activity looking for better jobs and income. They have less than 2,500 inhabitants.

Semi-urban municipalities are transitioning from rural to urban areas, combining agricultural and forestry activities with small industries, commerce and

Chihuahua and Morelos had the highest crime rates in the country, surpassing the national average. Likewise, the states of Chihuahua, Guerrero, Durango, Sinaloa and Tamaulipas concentrated the largest homicide rates in the country. See, INEGI, Tasa De Incidencia Delictiva Por Entidad Federativa De Ocurrencia Por Cada Cien Mil Habitantes, INEGI, (Oct. 28, 2019), https://wrerw.inegi.org.mx/temas/incidencia/.

9 The Centro de Estudios Económicos del Sector Privado states that insecurity, impunity and corruption affect the assets of individuals and companies, especially those of micro and small companies; this situation also limits economic growth, inhibits investment and welfare. See, Centro de Estudios Económicos del Sector Privado, Análisis Económico Ejecutivo, CEESP.ORG.MX, (Oct. 1, 2018), http://ceesp.org.mx/wp-content/uploads/2018/10/AEJE_01Oct18.pdf.

10 The Peace Index Mexico 2018, prepared by the Institute for Economics and Peace (2019), mentions that in 2017 violence in the country had an economic impact of at least 4.72 billion pesos (249 billion dollars), which amount to $21 \%$ of the national GDP. This impact is seven times greater than the education budget and eight times greater than public investment in health for the same year. See, Institute for Economics \& Peace, Índice de Paz México 2019, Sidney: Institute For Economics \& Peace; Vision Of Humanity (2019), http://indicedepazmexico.org/.

11 INEGI, Encuesta Intercensal 2015, INEGI, (Oct. 11, 2015), https://wrwre.inegi.org.mx/pro gramas/intercensal/2015/.

12 Miguel Cervera Flores, J. Walter Rangel Gonzalez, Distribución de la Población por Tamaño de Localidady su Relación con el Medio Ambiente, Dirección General de Estadísticas Sociodemográficas, INEGI, (February, 2015), https://wrew.inegi.org.mx/eventos/2015/Poblacion/doc/p-WalterRangel.pdf. 
services; these municipalities have a population that ranges between 2,500 and 15,000 inhabitants.

Urban municipalities are characterized by the presence of highly developed companies and small and medium-sized industries that foster their development. They have a population between 16,000 and 699,999 inhabitants, so they have more complex needs and demands in terms of public services, economic development and public safety, among others.

Finally, metropolitan municipalities are those integrated by other urban municipalities and have the characteristics of mega cities (they have an average population of 700,000 to 1 million inhabitants). Given their geography, they are close to state capitals, with political and administrative dimensions that makes them share problems, needs and interests. ${ }^{13}$ Currently, Mexico has 74 metropolitan areas. ${ }^{14}$

Taking the above into consideration, municipalities with urban characteristics can implement a Fiscal Information Analysis Units with the characteristics that we will mention further on.

\section{Constitutional Municipal Faculties \\ that Generate the Databases Reguired to Implement the Public Policies to Gontrol Criminal Assets}

In accordance with article 115 of the Constitution of the United Mexican States, municipalities are autonomous and have a governmental capacity in all matters that the Constitution grants them; ${ }^{15}$ that is to say, they do not require any mediation to exercise the faculties allocated to them in the Magna Carta. The Mexican federal system applies a faculty formula between government orders rather than a hierarchy formula, such as the one in North America's federalism.

Therefore, in Mexico the different levels of government have the same hierarchy and, in a state of constitutional normality, it depends on the faculty of each level to determine which one has predominance over a specific function. In sum, municipalities can decide and be responsible for themselves and, hence, for everything related to the databases derived from these faculties. These databases are the raw material required to develop the intelligence products proposed by the public policy.

13 For more information regarding metropolitan areas please refer to annexes 1, 2, 3 and 4. See, Conapo, Inegi, Sedatu, Segob, Delimitación de las zonas metropolitanas de México 2015 (2015).

14 For information regarding the Delimitation of Metropolitan Areas in Mexico please refer to Annex 5. See, Conapo, Inegi, Sedatu, Segob, Delimitación de las zonas metropolitanas DE MéXICO 2015 (2015).

15 Pedro Torres, la Autonomía Municipal y su Garantía Constitucional Directa de Protecaión. Estudio Comparado de los Supuestos Español y Mexicano 282, 283 (Universidad Nacional Autónoma de México, 2005). 
In addition, municipalities have the faculty to decide how to spend their money, since they approve the expenditure budgets of their own resources. However, the power to collect taxes or royalties has to be granted by the income laws approved by each state's congress every year.

Municipalities have the right to propose tax rates, as well as tax and royalty scales, and the State Congress decides whether to approve or reject these proposals. All charges must be enabled by law. ${ }^{16}$ Ultimately this is where the catalogue of databases of the fiscal Units, which we will discuss in this article, come from.

Before addressing the faculties granted by the Constitution, it is important to note that each state can regulate the way it implements its laws and public policies. Let us remember that federal models (Mexico, Brazil, Argentina and the United States) grant the states the possibility to adjust constitutional law, while respecting the frames it provides. ${ }^{17}$ Therefore, and in order to understand the behavior of each municipality, it will be necessary to examine their sub-national particularities. There are even some municipalities that yield some of the faculties that the Constitution confers upon them to the state to which they belong. ${ }^{18}$

According to the Constitution, municipalities will receive the contributions and any additional taxes on real state, their subdivision, division, consolidation, transfer and improvement, determined by the states, as well as those regulated by real estate value modifications, in accordance with article 115. Clearly, these faculties also include databases.

As can be observed, municipalities are mainly responsible for collecting land related taxes. In addition to the above, municipalities collect the rights and royalties for which they are constitutionally enabled. ${ }^{19}$

Article 115 fraction III of the Mexican Constitution establishes that municipalities also have the following faculties: 1) drinking water, 2) drainage, 3) sewerage, 4) waste water treatment and disposal, 5) public lighting, 6) waste

16 Constitutional Controversy 163/2016, Suprema Corte de Justicia de la Nación [S.C.J.N], [Supreme Court], 13 de febrero de 2018, (Mex.); Constitutional Controversy 14/2004, Suprema Corte de Justicia de la Nación [S.G.J.N], [Supreme Court], 22 de diciembre de 2004, (Mex.).

17 José María Serna, El Sistema Federal Mexicano (Porrúa, 2009); Pedro Torres, El modelo federal mexicano a la luz de los modelos comparados. La necesidad de la incorporación en la constitución de los principios de subsidiariedad y solidaridad como principios informadores y delimitadores del sistema de competencias, in Isotimia 2, 87,97 (Editorial Porrúa, 2009).

18 The company Servicios de Agua y Drenaje de Monterrey, which provides water and drainage services to the municipalities of the metropolitan area, functions as an example. In the international context, Barcelona's metropolitan area that comprises 36 municipalities was created in 2010. One of its faculties is to supply water. See, Law 31/2010 of Barcelona Metropolitan Area, Parliament of Catalonia, July 27, 2010.

19 The Federal Tax Code defines duties as the contributions established by law for the use or exploitation of the Nation's public domain assets and royalties corresponding to earnings resulting from public-law functions other than contributions, income derived from financing and those obtained by decentralized agencies. See, Código Fiscal de la Federación [G.F.F] [Federal Tax Code], as amended, Diario Oficial de la Federación [D.O.F], 31 de diciembre de 1981 (Mex.). 
cleaning, collection, transfer, processing and final disposal, 7) markets, 8) central distribution markets, 9) cemeteries, 10) slaughterhouses, 11) streets, and 12) parks, gardens, and public security; pursuant to article 21 of the Constitution (police and transit).

Besides the faculties already set forth, the local legislature of each state assigns other faculties to their municipalities, namely, states may expand the faculties of their municipalities derived from their residual faculties. ${ }^{20}$

In addition to the foregoing, in terms of the corresponding federal and state laws, article 115, fraction V, grants municipalities the following faculties: 1) to formulate, approve and administer the municipalities' urban development zoning and planning processes; 2) to participate in the creation and management of its territorial reserves; 3) to take part in the formulation of regional development plans; 4) authorize, control and monitor land use; 5) to get involved in urban land ownership regularization; 6) to grant construction licenses and permits; 7) to take part in the creation and management of ecological reserves and the development and implementation of their management programs; 8) to contribute in the formulation and implementation of public passenger transport programs, when they affect their territorial scope.

These are the faculties directly granted by the Mexican Constitution. However, some general laws also grant them other faculties not expressly stated in the Constitution, as is the case of the General Civil Protection Act. ${ }^{21}$ Nevertheless, for purposes of what we want to demonstrate, constitutional faculties suffice to evidence the general hypothesis of this article, which is that municipalities are strategic in the control of criminal assets and the creation of a national system to control criminal assets.

Further on, we will describe how a municipal government is organized in order to understand its structure and, based on its faculties, justify which municipal instance must be responsible for the ORPI alters resulting from its public policy, understand its basis and what is the main input required to develop an effective public policy to control assets in a federal model.

\section{Municipal Organization and Databases}

Municipalities are governed by a town hall chaired by the municipal president, who in turn works with a municipal secretary and treasurer. ${ }^{22}$ Further on, we

20 The residual principle applies in federal systems; that is to say, anything that is not expressly assigned to the federation belongs to the states.

21 Published on June 6, 2012 in the Official Journal of the Federation. An example of a municipal faculty in the field of civil protection is the one set forth in article 84, regarding the creation of a population's public and private patrimonial risks' atlas.

22 Municipalities are organically regulated in each state through their constitution and by an organic law issued by the state legislature, where the main functions of each municipal public servant are defined. 
will go over the names of some of the ministries that control information relevant for the public policy; however, different states and municipalities can have different names for these ministries or directorates, according to their local norms and standards. ${ }^{23}$

In accordance with its faculties and functions, the municipal treasury must be the area mainly responsible for issuing alerts and developing intelligence products since, as we have already analyzed, this area controls most of the municipality's information, through its municipal fiscal records. At the end of the day, most municipal proceedings are registered in the budgets and records, both for incomes and expenditures.

As previously stated, there is a wide range of municipalities with various sizes and institutional strengths. Urban municipalities may be able to develop intelligence products that alert other government agencies, ${ }^{24}$ since information is their basic input.

The political will of the municipal president is crucial for the existence and quality of its databases to become a public policy because, without this premise, the proposed public policy will suffer a structural weakness.

Furthermore, another issue that has to be addressed is the lack of political will in the municipalities' various areas regarding the creation, access and delivery of the updated databases to their treasuries. While all public policies risk colliding with bureaucracies that can derail or even make them fail, the political will of decision-makers will be vital to sustain them, in addition to imposing on, and convincing bureaucratic elites of implementing them, as well as punishing those who do not.

Information can tangibly expose some of the areas of opportunity of local governments. For example, it can identify that a certain unit has materially decreased its inspection or verification processes or its ability to collect fines. Economic registries will represent the main certainty for this policy.

Another issue is to establish that databases should be centralized in the treasury and, if this is not the case or if it is not possible to do so, then the treasury will need direct access to the databases of all the ministries that generate acts over which it must collect an income, in real time. ${ }^{25}$

In this sense, treasuries will register individuals' patrimonial and economic activities through payments made by taxpayers, derived from taxes, fees and royalties, to create a patrimonial profile of individuals and the main activities

23 It is important to say that the municipality of General Escobedo in the State of Nuevo Leon was chosen as sample because the field work for this research was carried out in the said community.

24 According to the INEGI, a community is considered to be rural when it has less than 2,500 inhabitants, while an urban community has more than 2,500 inhabitants. See, Población rural y urbana, INEGI (August 25, 2019), http://cuentame.inegi.org.mx/poblacion/rur_urb.aspx?tema=P.

25 Obviously, the technological element is very important, and we refer to the platform that concentrates the information. However, this cannot be a valid pretext for municipalities with a regular institutional capacity to stop generating and ordering their information. 
Esta revista forma parte del acervo de la Biblioteca Jurídica Virtual del Instituto de Investigaciones Jurídicas de la UNAM

developed in their community. Some of the payments registered by treasuries are listed in Table 1.

Table 1. Payments Registered by Municipal Treasuries

\begin{tabular}{|l|l|}
\hline \multicolumn{2}{|c|}{ Treasury } \\
\hline Municipal cadaster & Tax credits' installments' database \\
\hline Municipal taxpayers' registry & Tax verifications' database \\
\hline Municipal suppliers' database & Ad endorsements' database \\
\hline Alcohol endorsements' database & Parking exclusivities' database \\
\hline Fiscal fines and penalties & Vacant lots' registry \\
\hline
\end{tabular}

Source: Garcia, Sylvia Camila, with information obtained from interview with municipal authorities (Oct. 21, 2019). ${ }^{26}$

As may be observed, the treasury's databases have a vast potential to identify, among other things, who owns land within the municipal borders or who is buying real state in a given period of time and place. It will be possible to verify if the owner's tax domicile is in the municipality, and if the domicile is congruent with the value of the properties. For example, tax domiciles located in abandoned houses for high-value properties lead us to assume that this profile is not the final beneficiary.

In Mexico, many of the resources resulting from drug trafficking have been used to purchase ranches and country houses. We must remember that it is a more flexible activity in fiscal terms, and that it is easier to transfer cash in many of its activities. Land related information is also concentrated by municipal authorities. ${ }^{27}$

Of course, state authorities also have access to this information through the public registry of property. However, as it has already been mentioned, regarding local entities, it is easier to identify these activities in the field. In municipalities, it is easier to spot the purchase of large amounts of land, atypical transac-

26 Interview with municipal authorities in Nuevo Leon, Mexico (Oct. 21, 2019).

27 According to the Proceso magazine, in 2018, the prosecutor's office seized the ranch of former Governor Roberto Sandoval, accused of illicit enrichment. See, Fiscalia de Nayarit prepara aseguramiento de otro rancho de exgobernador Sandoval, Proceso (Mexico) (April 12, 2018), https:// wererceproceso.com.mx/529658/fiscalia-de-nayarit-prepara-aseguramiento-de-otro-rancho-del-exgobernadorsandoval. Likewise, the Attorney General of the State of Chihuahua seized 4 ranches belonging to the state's former governor Cesar Duarte, which exceeded 2 thousand hectares, after being accused of illicit enrichment. See, Asegura FGE otros 4 ranchos de Duarte; superan las 2 mil hectáreas de extensión, El Heraldo de Chinuahua (Mexico), 26 de febrero de 2018. Further, by the middle of 2019 the auctioning process of ranches, mansions and safe houses linked to drug trafficking started. The expectation was to obtain at least 368 million pesos. See, Diego Oré, México subasta ranchos, mansiones y casas de seguridad de narcos, ReuTERs, (June 23, 2019), https://lta.reuters.com/ar ticulo/mexico-narcos-subasta-idLTAKCN1TOORL-OUSLT. 
tions and investments in land, purchase of livestock (municipalities have the farmers' registry through the livestock registry), among others.

Another important piece of information may be who holds the updated alcohol endorsements; that is to say, who controls the alcohol's points of sale and how this trend has been configured. For example, review what brands concentrate the permits, who owns the bars, deposits or canteens, and which ones are the most problematic.

Fines resulting from alcohol illegal sales, or quarrels or scandals, are important information, for example, to renew permits or authorizations for those establishments. ${ }^{28}$ If there is no information available, the Authority's decisions will seem arbitrary.

As for the water service supply's databases, although in many municipalities this service is provided by decentralized bodies of the municipal administration, we cannot lose sight of the fact that it is a local faculty. In this regard, having the beneficiaries' information will help cross examine the information to verify commercial or residential properties.

Meanwhile, City Hall generates the following databases related to collections made by the municipal treasury, as listed in Table 2.

\section{Table 2. Databases Generated by Gity Hall}

\begin{tabular}{|l|}
\hline \multicolumn{1}{|c|}{ City Hall } \\
\hline Vacant lots' registry (together with the Finance Ministry) \\
\hline Businesses' going out of business \\
\hline Inspections, controls and supervision fines \\
\hline Fixed and semi-fixed business' census \\
\hline Street vendors' registry \\
\hline Street markets tenants' registry (tianguis) \\
\hline Municipal markets \\
\hline Civil protection \\
\hline Sanctions derived from the Public Entertainment Rules \\
\hline Approvals \\
\hline
\end{tabular}

Source: Garcia, Sylvia Camila, with information obtained from interview with municipal authorities (Oct. 21, 2019). ${ }^{29}$

Derived from its inspections, the municipality may also have information in reference to the commercial establishments that violate regulations. The Inspection Department can provide information resulting from its visits, espe-

28 In some states, municipalities issue the permits directly, while in others the approvals are granted by the municipalities, and the state issues the permits.

29 Interview with municipal authorities in Nuevo Leon, Mexico (Oct. 21, 2019). 
cially if it uses closed and open fields, with key words to verify information that is important for the municipality. For example, it can verify if the information provided by local taxpayers is real. In case of false information, an alert would be sent to the municipal analysis unit, which we will discuss further on.

The businesses' census, as well as the street vendors' and markets' registries can help identify individuals, trade unions or organizations that use this type of figures to generate "funnel accounts" used to introduce or remove money from the financial system. ${ }^{30}$ In some cases, licit and illicit money are combined and all this information can help identify possible tax discrepancies with field information, or even crimes.

Public entertainment permits or approvals can also provide interesting information; for example, dancing and rodeo permits and approvals for cockfights, horse racing and raffles, among others. While it is true that permits are issued by the Ministry of the Interior, the municipality must also give its consent. ${ }^{31}$ Also, the municipality is able to verify certain information through the Municipal Public Entertainment Rules; for example, if shows are a simulation to introduce illegal money into the financial system; ${ }^{32}$ hence the importance of municipal alerts. Although the financial system is not a municipal issue, it can provide information to either the Secretaria de Hacienda y Crédito Público (SHCP for its acronym in Spanish) Financial Intelligence Unit (henceforth FIU) or its counterparts in the states.

The Urban Development and Ecology Ministry, responsible for ordering the land within the municipality's borders, also controls very important information. The databases generated by this ministry are listed in Table 3.

\section{Table 3. Urban Development and Ecology}

\section{Ministry Databases}

\begin{tabular}{|l|}
\hline \multicolumn{1}{|c|}{ Urban Development and Ecology Ministry } \\
\hline Land use, building and construction permits' requests \\
\hline License applications for mergers, parcellations, subdivisions and re-parceling databases \\
\hline Urbanization works' database \\
\hline Urban projects' database \\
\hline Authorized street publicity \\
\hline Commercial and industrial services' regularization database \\
\hline Environmental sanctions' database \\
\hline
\end{tabular}

30 Funnel accounts are used to drop small amounts, so they do not stand out.

31 SEGOB, Requisitos para Peleas de Gallos, Gobierno de México, (Oct. 10, 2019), http:// wrew.juegosysorteos.gob.mx/es/fuegos_y_Sorteos/Peleas_de_gallos.

32 For example, the number of tickets paid in cash for public entertainment and dances can be simulated in order to introduce money into the financial system. 


\begin{tabular}{|l|}
\hline \multicolumn{1}{|c|}{ Urban Development and Ecology Ministry } \\
\hline Urban development inspection and proceedings' database \\
\hline Urban development sanctions' database \\
\hline Environmental protection sanctions' database \\
\hline Nomenclature Rules sanctions' database \\
\hline Road Access Rules sanctions' database \\
\hline
\end{tabular}

Source: Garcia, Sylvia Camila, with information obtained from interview with municipal authorities (Oct. 21, 2019). ${ }^{33}$

As previously mentioned, urban development areas are very important because they control the information of the areas where more money is invested in the municipalities, such as constructions, industrial developments, farms and commerce and housing, among others. In some cases, satellite photos of the constructions are used for cadastral modernization. ${ }^{34}$

To start with, it can be stated that, at least formally, land use information is available. The municipality can close down a work that doesn't have that required permits and that way it can develop an information registry of the individuals building inside its boundaries. This is one of the basic inputs required to understand the patrimonial activities of individuals or their final beneficiaries.

It is necessary to highlight land use, building and construction licenses' information and license requests for mergers, parceling, subdivisions and divisions into lots, as well as urban development inspections and proceedings. ${ }^{35}$ If each municipality had well-ordered and up-to-date databases, it would have quality raw material to control criminal assets.

Finally, the municipality has information on the pawnshops opened within its borders. It is important to know who they belong to or who is their legal representative. Although this information is not controlled by municipalities, it is public information filed in the Public Commerce Registry. ${ }^{36}$

Financial matters are controlled by federal courts and involve issues related to the financial system (banks, insurance companies, bonding companies

33 Interview with municipal authorities in Nuevo Leon, Mexico (Oct. 21, 2019).

34 Cadastral modernization refers to the municipality's updated construction atlas, to calculate property taxes.

35 It is important to say that the person or entity requesting the permit is not always the final beneficiary. Nevertheless, providing ownership evidence can help authorities and give information on the individuals or entities that request the permits.

36 The incorporation, transformation, merger, spin-off, dissolution and liquidation of a company can be reviewed in real time in the web site. This information is very important to know who are the individuals behind the companies. See, Registro Público de Comercio [R.P.C] [Public Registry of Commerce], 8 de agosto de 2018 (Mex.), https://rpc.economia.gob.mx/siger2/xhtml/ login/login.xhtml. 
and retirement funds' administrators (AFOREs), among others). ${ }^{37}$ Although there is a lot of money involved, a large part of it is also invested in real estate and it is the municipalities who control the most relevant information. We must also mention the states, which control vehicle database; where a large amount of the offenders' resources are spent. This article will only deal with municipal databases.

If a person is involved in a crime, besides proving his or her guilt before a judge, the money involved must be recovered to compensate the victims; ${ }^{38}$ it is also necessary to verify what other assets are the product of the criminal's illicit activities and seek for said assets to be transferred to the state's ownership.

In addition to their illegal origin, many of the criminal's assets are also used as tools to commit crimes. We believe that the best way to win this battle is, as in conventional wars throughout history, by gaining ground, taking away the opponent's weapons, its attack weapons (land, air and sea vehicles) being money provision logistics and supplies.

Without money, criminals cannot pay bribes or their employees' payroll; criminal organizations are paralyzed and their physical and economic mobility structures are eliminated. Therefore, it is important to promote that municipalities issue alerts. Additionally, municipal databases are an important source of information for prosecutors, who may rely on them to define the criminals' patrimonial profile, mainly in municipalities where it is presumed that they may own assets, so they can verify that they are not the proceeds of crime. Similarly, if the said assets are illegally obtained, this will make it easier to locate them in order to initiate legal proceedings and take away the offenders' rights on the said assets. ${ }^{39}$

Lastly, the Public Services Ministry also generates information such as the "public garbage service taxpayers' database". This database is important to

37 The Mexican banking system is integrated by the Bank of Mexico, commercial banks, development banks and public trusts incorporated by the Federal Government for economic development purposes, as well as banking self-regulating agencies. Refer to article 3 of the Credit Institutions Law. Likewise, the financial entities that make up the Mexican financial system are the following: a) financial groups holding and sub-holding companies, $b$ ) credit institutions, c) brokerage houses, d) stock exchanges, e) investment funds, f) fund operators, $g$ ) investment fund distribution companies, $h$ ) bonded warehouses, $i$ ) credit unions, exchange houses, $j$ ) multipurpose regulated financial companies, $k$ ) financial cooperative associations, $l$ ) securities depositary institutions, central counterparties, $m$ ) rating institutions, $n$ ) financial technology institutions, o) credit information societies, $p$ ) financial community partnerships under the supervision of the Commission and the rural financial integration entities, as well as other institutions, $q$ ) public trusts with financial activities supervised by the Commission; all of them incorporated under commercial and financial laws. In addition to the above, the savings and credit cooperatives make up the financial system. See, Ley de la Comisión Nacional Bancaria y de Valores [L.C.N.B.V] [National Banking and Securities Commission Law] (Mex.).

38 Under the Expired Ownership Act, the prosecutors' offices must issue a protocol for prosecutors to give notice when there is an ORPI related offence.

39 See, Ley Federal de Extinción de Dominio [L.F.E.D] [Federal Law of Extinction of Domain], Diario Oficial de la Federación [D.O.F]. 
understand how many people use this service and to verify the veracity of the information provided by citizens; for example, a property originally registered as a vacant lot, where there is actually is a shopping mall that hasn't been registered and that is receiving garbage collection services without paying the corresponding taxes.

It is important to say that the information that may be obtained and validated through the municipality can be used not only to locate money resulting from criminal activities, but also to detect local, state and federal tax evasion, as well as fiscal discrepancies and ORPIs.

In this article we're going to focus on financial information, but it is important to mention that public safety areas also generate information through their analysis areas, although it is usually criminal rather than financial or fiscal information. Next, we're going to talk about the area that should implement this public policy.

\section{Municipal Tax Information Analysis Areas}

Once the legal design has been developed and before the Unit begins to operate, it is important to integrate it into the municipal rules. As we know, for an authority to act it must be granted the required faculties within the regulatory framework.

Consequently, this new Unit has to be included in the organic rules of the municipality. The Unit would need to depend on the treasury since, as we have already discussed, the basic information to develop the intelligence products is generated there.

Also, another element that has to be defined in the rules is this new Unit's functions, which must at least include the following:

1) To define the guidelines to register the information regarding the activities for which the municipality collects money. That is to say, the Unit must establish the report formats, either in a centralized database or for each ministry. It would be advisable to have one centralized database.

2) To issue a report on the quality of the information regarding the information generated in the municipal databases, so decision-makers may be aware of the public policies institutional weaknesses or strengths, since the quality of the information is its basic input.

3) To generate products to identify how each municipality functions and behaves, i.e., how is it performing within its assigned faculties; for example, how many fines are being issued during each month, how many permits are being granted or how many taxes have been collected. This information will make it possible to identify the behavior of each municipal area and generate alerts on the ministries' atypical behaviors and their activity or lack of activity. 
4) To generate periodic reports on the municipality's strategic, tactical and operational risks. For example, a strategic risk would be land ownership concentrated by highly aggressive speculative companies; a tactical risk would be the opening of an atypical number of pawnshops and an operational risk would be to identify a crime leader or criminal family with economic and patrimonial interests in the municipality. In the following heading we will explore the products in more detail.

5) To identify the patrimonial activity of politically exposed individuals in the municipality ${ }^{40}$ or to generate the information requested by the prosecutor regarding specific objectives with economic or fiscal activity in the municipality.

In short, the Unit must analyze the fiscal and economic behavior of the municipal organization and generate alerts regarding economic and patrimonial risks that loom over the municipality.

\section{The Unit's Structure and Basic Products}

The organization of a Unit of this type has to include identifying the size of the municipal population, the number of the treasury's and other areas' annual transactions, as well as defining the products it wants to generate.

Its basic structure includes the following functions: one Unit manager, who will head it and be responsible for the products it generates. It must also include two areas able to deploy a number of analysts, according to the needs of the municipality.

One of these areas would be responsible for compiling and processing information, and the other would be responsible for analyzing it. The main function of the area responsible for collecting and processing information will be to gather all the information required to develop the expected products, so that the analysis area may access it.

For example, part of its faculties would be to define the formats required to register information, as well as to identify new databases, either municipal or belonging to other public and private entities, as well as to sign information exchange agreements. The more well-ordered information the Unit has, the faster and more powerful it will become.

The analysis area would use various scientific and empirical methods to analyze the information and generate the intelligence products required for decision-making, according to its public policy.

A Unit of this type must at least generate the following products:

1) To design a public policy to prevent ORPIs in the municipality. This product will determine where the municipality will focus its activity. That is to

40 Personas Políticamente Expuestas, [Politically Exposed People] Secretaría de Gobernación, 2 de octubre de 2019 (Mex.). 
say, the Unit has to stablish where it is going to concentrate its inputs and human resources to give preference to monitoring certain products over others, using its intelligence products to prevent ORPIs.

For example, touristic municipalities will need to be more attentive to investments made in hotels and bars; other municipalities with an industrial vocation will have to pay close attention to warehouses inside its territory. This product is the basis of the public policy for the analysis of tax municipal information and its purpose is to analyze and determine why it should focus its public policy on those activities rather than on others. An important criterion is to define the most relevant risks for the municipality and its inhabitants, at present and in the future.

2) To generate a report on the municipal databases and their quality. This is of the utmost importance since the existing raw material has to be evaluated systematically, "this is the clay to make bricks".

As already mentioned, it is very important for municipalities to be aware of how land ownership moves in order to be able to identify possible behaviors that may affect municipal life. This is why it is important to make reports on land concentration or atypical purchases and it may also help create alerts. The path and use of money help develop tangible scenarios and assumptions regarding what is happening and what may happen in the municipality.

It will be necessary to have a control panel to monitor the tax activities of the various municipal areas. For example, to supervise how the trend of the fines imposed throughout the year, derived from civil protection matters, is handled, or to identify the activity or lack of activity of a specific municipal area. ${ }^{41}$ It will also help monitor the decrease of its income and why the said income has decreased; for example, a large number of fines being imposed or the opposite, or a sharp drop on tax collection. This information sends an alert to try to identify why things are happening.

In the end, we must be clear that an alert is a warning call to focus on the required efforts to try to explain what is happening or what may happen, using scientific or empirical methods.

3) The Responsible Citizen Certificate, which certifies that citizens are not indebted to the municipality. In case a person has not paid a fine, he/she will not receive this certificate so he/she will not be able to process construction or land use permits. This can only be achieved if databases are well ordered and preferably concentrated in one single area. This increases the fulfilment rate of citizens' obligations before the municipality and provides greater governance to avoid impunity, through a more effective collection of administra-

41 The concept of civil protection encompasses the coherent set of actions designed to respond to the needs and demands raised by society, the imminence or culmination of a disaster that puts the lives, property and surroundings of its members at risk. See, Gonzalo Campos, Evolución legislativa de la protección civil en Mexico, in Protección Givil. RéGimen Jurídico de Protecaión Givil en México 283, 301 (Laguna Publishing House, 2001). 
tive offenses. With some exceptions, nowadays municipalities have lost their authority due to the existing impunity in implementing sanctions. ${ }^{42}$

Another report that Units may be required to prepare in case their public policies require it is the one related to their patrimonial behavior of their public servants or politically exposed persons. In the case of public servants, the municipality will have information related to his/her assets' statement in order to identify any unexplained increase of the official's assets. As for politically exposed persons, at present they're not required to generate an alert before the FIU but, in case a possible crime is identified, they are obliged to report it to the local or federal prosecutor, as it may be the case. ${ }^{43}$

\section{Conclusion: Implementation and Consolidation Risks OF THESE NEw UNITS}

Every law or public policy has risks related to its implementation process. In this case, the main risks may include the following issues:

1) Lack of political will. If municipal presidents do not prioritize this public policy in their public agenda it will be difficult for it to work, since the Unit requires the information produced by all municipal areas. If the municipal president does not assume its leadership and supports the Unit, it will lack the basic input for it to function, namely information.

2) The temptation to use the Unit for purposes other than those it was designed for, such as for political purposes. This would mean its institutional death sentence and it would also represent a great risk, since it would be enough for the people being attacked to come into power for them to dismantle the Unit and start over.

Creating quality databases grants a lot of power, but it is a long and laborious process that is normally not achieved in one period of government. In this regard, we have observed that, in the federal order, when this type of phenomena has taken place, people in power chose to dismantle these institutions, as in the case of the Center for Investigation and National Security (CISEN for its acronym in Spanish). ${ }^{44}$

42 The report Perspectivas OECD: México Políticas Clave para un Desarrollo Sostenible notes that taxes represent the larger part of Mexican municipalities' income, but that their implementation is uneven. It also states that the local tax administration and administrative collection should be reinforced. See, Report Perspectivas OECD: México Políticas Clave para un Desarrollo Sostenible (October, 2010), https://wwweoed.org/Mexico/45391108.pdf.

43 Politically exposed individuals are included in the following list. The SHCP Financial Intelligence Unit issues it for financial agents to report their activities in the system. See, Personas Políticamente Expuestas (October 3, 2019), https://wrw.gob.mx/cms/uploads/attachment/ file/46540/Personas_Politicamente_Expuestas_Nacionales.pdf.

44 For a long time, this institution was used to weaken the government's political adversaries. It was reopened by the current left-wing government. 
3) The possibility that government changes substantially revoke or modify this public policy. If the Unit manages to consolidate a technical and independent profile, its institutional strength will increase. During its consolidation stage, we also consider it risky to submit it to a political corruption process, since political forces will control it with all their might. When greater strength and institutional consolidation are achieved, we do not see any risk in providing information in corruption cases.

During the first stage, it will be important to focus on the crimes that most affect the municipality, taking away from criminals that have broken the law all that they have obtained. For example, assets that result from human trafficking, kidnapping or drug dealing offences.

4) The possibility that the Unit is infiltrated by crime, meaning it could have information about money mobility in the region and who owns it. This can be a great challenge and demonstrates the need to take special care of the Unit, in identifying profiles and, above all, the person that heads it. It will be important for its members to have good salaries and professional careers to reduce the temptations of selling information.

5) That the Unit is unable to obtain information from all the municipal areas, or from other levels of government (federal, state and other municipalities), based on agreements.

The institutional legitimacy of the Unit will depend on the extent to which its products add value to decision making in other areas of the local government. If this does not occur, it will lose credibility and institutional strength. For the Unit to work it requires information and, if the areas do not provide it, they will obviously be betting on the failure of this public policy.

Not all municipalities in the country will be able to have a Unit that generates all the products of which we speak. However, in accordance with their institutional capacities, they will be able to create a Unit according to their local needs.

Regardless of the Unit, municipalities urgently need to develop databases that give them the possibility to make decisions based on evidence. The big problem of underdeveloped countries is that they do not have the required information to make decisions. ${ }^{45}$

45 Francis Fukuyama, La Construcción del Estado. Hacia un nuevo orden mundial EN EL SIGLO XX 20 (Ediciones B, 2004); Peter May, Claves para diseñar opciones de politicas, in ANtologías, Problemas Públicos y Agenda de Gobierno 235-256 (Miguel Ángel Porrúa, 2017). With regard to resources as a key part of the analysis and management of public policies, legal remedies are considered to be the regulatory backbone of the political-administrative program that structures their content such as the selection of other resources (organizational, procedural or financial). Information is another resource (cognitive resource), through which information provides the basis required for the decision-making phase. Other resources are the human, economic, relationships or interactive resources, as well as chronological, patrimonial and trusted resources, political support (majority resources) and strength (violence resource); the violence resource is used in dictatorial regimes and it is only used in democratic regimes under extreme duress. See, Joan Subirats, Análisis y Gestión de Políticas Públicas 71,94 (Ariel, 2012). 
Esta revista forma parte del acervo de la Biblioteca Jurídica Virtual del Instituto de Investigaciones Jurídicas de la UNAM

To strengthen the figure of the Municipal Information Analysis Unit, it is necessary to create regulations that establish its form of operation. In this way, its operation will be guaranteed in the short and long term.

The information that the Municipal Unit will analyze, due to its characteristics, will have to guarantee the protection of the personal data of taxpayers and their rights.

Therefore, the municipalities must design dissemination strategies about the objective of the analysis units, guaranteeing transparency in their operation.

VIII. ANNEXES

Annex 1. Metropolitan Areas Defined Based on Intermunicipal or Interstate Conurbations

\begin{tabular}{|c|c|c|}
\hline Metropolitan Area & State & $\begin{array}{c}\text { Total Number } \\
\text { of Municipalities }\end{array}$ \\
\hline National & National & 417 \\
\hline Aguascalientes & Aguascalientes & 3 \\
\hline La Laguna & $\begin{array}{c}\text { Coahuila de Zaragoza- } \\
\text { Durango }\end{array}$ & 5 \\
\hline Monclova-Frontera & Coahuila de Zaragoza & 4 \\
\hline Piedras Negras & Coahuila de Zaragoza & 2 \\
\hline Saltillo & Coahuila de Zaragoza & 3 \\
\hline Colima-Villa de Álvarez & Colima & 5 \\
\hline Tecomán & Colima & 2 \\
\hline Tuxtla Gutiérrez & Chiapas & 5 \\
\hline Valle de México & $\begin{array}{c}\text { Mexico City- } \\
\text { Hidalgo-Mexico }\end{array}$ & 76 \\
\hline Moroleón-Uriangato & Guanajuato & 2 \\
\hline San Francisco del Rincón & Guanajuato & 2 \\
\hline Pachuca & Hidalgo & 7 \\
\hline Tulancingo & Hidalgo & 3 \\
\hline Guadalajara & Jalisco & 10 \\
\hline Ocotlán & Jalisco & 3 \\
\hline Puerto Vallarta & Jalisco-Nayarit & 2 \\
\hline Tlanguistengo & Mexico & 6 \\
\hline Toluca & Mexico & 16 \\
\hline La Piedad-Pénjamo & $\begin{array}{c}\text { Guanajuato-Michoacán de } \\
\text { Ocampo }\end{array}$ & 2 \\
\hline Morelia & Michoacán de Ocampo & 3 \\
\hline
\end{tabular}


Esta revista forma parte del acervo de la Biblioteca Jurídica Virtual del Instituto de Investigaciones Jurídicas de la UNAM

\begin{tabular}{|c|c|c|}
\hline Metropolitan Area & State & $\begin{array}{c}\text { Total Number } \\
\text { of Municipalities }\end{array}$ \\
\hline Zamora & Michoacán de Ocampo & 2 \\
\hline Cuautla & Morelos & 6 \\
\hline Cuernavaca & Morelos & 8 \\
\hline Tepic & Nayarit & 2 \\
\hline Monterrey & Nuevo León & 18 \\
\hline Oaxaca & Oaxaca & 24 \\
\hline Tehuantepec & Oaxaca & 5 \\
\hline Puebla-Tlaxcala & Puebla-Tlaxcala & 39 \\
\hline Tehuacán & Puebla & 2 \\
\hline Teziutlán & Puebla & 2 \\
\hline Querétaro & Guanajuato-Querétaro & 5 \\
\hline Cancún & Quintana Roo & 2 \\
\hline Rioverde & San Luis Potosí & 2 \\
\hline San Luis Potosí & San Luis Potosí & 3 \\
\hline Villahermosa & Tabasco & 2 \\
\hline Tampico & $\begin{array}{l}\text { Tamaulipas-Veracruz de } \\
\text { Ignacio de la Llave }\end{array}$ & 5 \\
\hline Tlaxcala-Apizaco & Tlaxcala & 19 \\
\hline Acayucan & Veracruz & 3 \\
\hline Coatzacoalcos & Veracruz & 3 \\
\hline Córdoba & Veracruz & 4 \\
\hline Minatitlán & Veracruz & 6 \\
\hline Orizaba & Veracruz & 13 \\
\hline Poza Rica & Veracruz & 5 \\
\hline Veracruz & Veracruz & 6 \\
\hline Xalapa & Veracruz & 9 \\
\hline Mérida & Yucatán & 11 \\
\hline Zacatecas-Guadalupe & Zacatecas & 5 \\
\hline
\end{tabular}

Source: CONAPO, INEGI, SEDATU, SEGOB. Delimitación de las zonas metropolitanas DE MÉxico 2015 (2015).

\section{Annex 2. Metropolitan Areas Based on Statistical and Geographical Criteria}

\begin{tabular}{|c|c|c|}
\hline Metropolitan Area & State & $\begin{array}{c}\text { Total Number } \\
\text { of Municipalities }\end{array}$ \\
\hline Tijuana & Baja California & 3 \\
\hline Chihuahua & Chihuahua & 3 \\
\hline
\end{tabular}


Esta revista forma parte del acervo de la Biblioteca Jurídica Virtual del Instituto de Investigaciones Jurídicas de la UNAM

\begin{tabular}{|c|c|c|}
\hline Metropolitan Area & State & $\begin{array}{c}\text { Total Number } \\
\text { of Municipalities }\end{array}$ \\
\hline Delicias & Chihuahua & 2 \\
\hline Hidalgo del Parral & Chihuahua & 2 \\
\hline Celaya & Guanajuato & 2 \\
\hline Chilpancingo & Guerrero & 5 \\
\hline Tula & Hidalgo & 2 \\
\hline Guaymas & Sonora & 2 \\
\hline Reynosa & Tamaulipas & \\
\hline
\end{tabular}

Source: CONAPO, INEGI, SEDATU, SEGOB. Delimitación de las zonas metropolitanas DE MÉxico 2015 (2015).

\section{Annex 3. Metropolitan Areas Defined by Size and Because They Are State Capitals}

\begin{tabular}{|c|c|c|}
\hline Metropolitan Area & State & $\begin{array}{c}\text { Total Number } \\
\text { of Municipalities }\end{array}$ \\
\hline Juárez & Chihuahua & 1 \\
\hline Durango & Durango & 2 \\
\hline León & Guanajuato & 2 \\
\hline Acapulco & Guerrero & 1 \\
\hline Culiacán & Sinaloa & 1 \\
\hline Hermosillo & Sonora & 1 \\
\hline La Paz & Baja California Sur & 1 \\
\hline Campeche & Campeche & 1 \\
\hline Guanajuato & Guanajuato & 1 \\
\hline Chetumal & Quintana Roo & 1 \\
\hline Ciudad Victoria & Tamaulipas & 1 \\
\hline
\end{tabular}

Source: CONAPO, INEGI, SEDATU, SEGOB. Delimitación de las ZONAS MEtropolitanas DE México 2015 (2015).

\section{Annex 4. Metropolitan Areas Based ON THEIR SEA AND LAND BORders}

\begin{tabular}{|c|c|c|}
\hline Metropolitan Area & State & $\begin{array}{c}\text { Total Number } \\
\text { of Municipalities }\end{array}$ \\
\hline Mexicali & Baja California & 1 \\
\hline Tapachula & Chiapas & 1 \\
\hline Nogales & Sonora & 1 \\
\hline Matamoros & Tamaulipas & 1 \\
\hline
\end{tabular}


Esta revista forma parte del acervo de la Biblioteca Jurídica Virtual del Instituto de Investigaciones Jurídicas de la UNAM

MUNICIPALITIES AS PART OF THE SYSTEM TO CONTROL CRIMINAL...

\begin{tabular}{|c|c|c|}
\hline Metropolitan Area & State & $\begin{array}{c}\text { Total Number } \\
\text { of Municipalities }\end{array}$ \\
\hline Nuevo Laredo & Tamaulipas & 1 \\
\hline Ensenada & Baja California & 1 \\
\hline Mazatlán & Sinaloa & 1 \\
\hline
\end{tabular}

Source: CONAPO, INEGI, SEDATU, SEGOB. DeLimitación de LAS ZONAS METROPOlitANAS DE MÉXICo 2015 (2015).

Annex 5. Criteria to Define Metropolitan Areas

\begin{tabular}{|l|c|}
\hline \multicolumn{1}{|c|}{ Criteria } & \# Metropolitan Areas \\
\hline $\begin{array}{l}\text { Based on an interstate or intermunicipal } \\
\text { conurbation }\end{array}$ & 47 \\
\hline Statistical and geographic & 9 \\
\hline $\begin{array}{l}\text { Due to their size and because they are } \\
\text { state capitals }\end{array}$ & 11 \\
\hline Coast and land borders & 7 \\
\hline
\end{tabular}

Source: CONAPO, INEGI, SEDATU, SEGOB. Delimitación de las zonas metropolitanas DE MÉXIco 2015 (2015). 